\title{
Fractions of heavy metals in soil after the application of municipal sewage sludge, peat, and furnace ash
}

\begin{abstract}
The effect of addition of different materials, i.e. sludge, ash and peat, as well as different doses of mixtures of ash and sludge and ash peat, on the total content of heavy metals $(\mathrm{Cr}, \mathrm{Zn}, \mathrm{Pb}, \mathrm{Cu}, \mathrm{Cd}, \mathrm{Ni})$ and their fractions was studied. Application of municipal sewage sludge, ash-sludge and ash-peat mixtures in the experiment caused a gradual increase in the content of studied heavy metals in soil. The ash was characterized by a low content of heavy metals as compared to municipal sewage sludge. After application of peat and its mixtures with ash a decrease of content of heavy metals was observed, and when the peat was used alone the greatest increase in the organic $\mathrm{C}$ content in the substrate could be seen. Distribution of heavy metals in the fractions separated in different combinations shows large variations, depending on the tested metal and the studied variant. Chromium, zinc, lead, and cadmium have been accumulated mainly in the residual fraction (FV), and most of the copper and nickel have been specifically bound with organic matter (FIV). It has been found that the alkaline materials application to the soil decreased the solubility of most heavy metals, which results in a limitation of their uptake by plants. Chromium and copper were an exception, since their solubility increased with the alkalinity of the substrate. An exception was chromium and copper, which solubility increased with the alkalinity of the substrate.
\end{abstract}

Key words: sewage sludge, peat, furnace ash, soil, fractions of heavy metals

\section{INTRODUCTION}

Application of ash-sludge and ash-peat mixtures to the soil not only improves the physicochemical properties of the substrate, but also enriches it in digestible macronutrients and micronutrients (Samaras et al. 2008). Incineration waste can be used as material improving the physical properties of reclaimed land and sustainably managed soils (Antonkiewicz 2011), as well as a material deacidifying soils and providing valuable components to plants (Sočo and Kalembkiewicz 2007). The use of municipal sewage sludge improves soil physicochemical properties. Municipal sewage sludge is a source of organic matter, macronutrients and micronutrients that can be used by plants (Sienkiewicz and Czarnecka 2012; Zhang et al. 2011). However, incineration ash and municipal sewage sludge can be a source of heavy metals and other organic pollutants (Dąbrowska et al. 2011). Peat as a natural material is a rich source of organic matter. Application of peat to the soil improves the sorption properties and increases the buffering capacity of the substrate (Al-Ani et al. 2014; Antonkiewicz 2008).

The main limitation in the application of sewage sludge and bottom ash can be a high content of heavy metals. Hence, the control of the soil and substrate to which the waste is used is necessary (Papadimitriou et al. 2008). Moreover, one should assess whether the use of waste helps to improve the physicochemical properties of the soil or substrate, for example reclaimed landfill.

The aim of the present article was to evaluate the effect of the addition of various materials, i.e. municipal sewage sludge, peat, and incineration ash, as well as various doses of ash-sewage sludge and ash-peat mixtures on some physicochemical properties of the soil, the total content of heavy metals and their fractions.

\section{MATERIAL AND METHODS}

\section{Characteristic of physicochemical materials used in experiment}

Research on the impact of municipal sewage sludge, incineration ash, peat and their mixtures on the physicochemical properties of soil was carried out after completion of the 3-year pot experiment. The study was conducted on very acid soil with a particle size of silt loam (Table 1). It contained $26 \%$ of sand, $69 \%$ of silt, $5 \%$ of clay. The furnace ash used in the pot experiment, in the terms of agronomic soil category 
TABLE 1. Characteristic of physicochemical materials used in experiment

\begin{tabular}{|c|c|c|c|c|c|}
\hline$=$ Parameter & Unit & Soil & $\begin{array}{l}\text { Sewage } \\
\text { sludge }\end{array}$ & Ash & Peat \\
\hline Texture & & $\begin{array}{l}\text { Silt } \\
\text { loam }\end{array}$ & - & $\begin{array}{l}\text { Sandy } \\
\text { loam }\end{array}$ & - \\
\hline $\begin{array}{l}\mathrm{pH}_{(\mathrm{KCl})} \\
\mathrm{pH}_{(\mathrm{H} 2 \mathrm{O})} \\
\text { Hydrolytic } \\
\text { acidity } \\
\text { Base exchange } \\
\text { capacity }\end{array}$ & $\begin{array}{l}\mathrm{pH} \\
\mathrm{pH} \\
\mathrm{mmol}(+) / \mathrm{kg}^{-1} \\
\mathrm{mmol}(+) / \mathrm{kg}^{-1}\end{array}$ & $\begin{array}{r}3.60 \\
4.73 \\
70.68 \\
42.45\end{array}$ & $\begin{array}{r}6.67 \\
6.82 \\
161.96\end{array}$ & $\begin{array}{c}9.85 \\
10.06 \\
\\
3.63\end{array}$ & $\begin{array}{r}4.82 \\
5.26 \\
831.94\end{array}$ \\
\hline $\begin{array}{l}\mathrm{C} \text { - Organic } \\
\mathrm{N} \text { - Total }\end{array}$ & $\mathrm{g} \cdot \mathrm{kg}^{-1}$ & $\begin{array}{c}18.48 \\
1.92 \\
\end{array}$ & $\begin{array}{c}219.16 \\
35.25\end{array}$ & $\begin{array}{c}23.69 \\
0.53\end{array}$ & $\begin{array}{r}370.50 \\
11.49\end{array}$ \\
\hline $\begin{array}{l}\mathrm{P}-\text { Available } \\
\mathrm{K} \text { - Available } \\
\mathrm{Mg} \text { - Available }\end{array}$ & $\begin{array}{l}\text { mg.kg-1 } \\
\text { dry mass }\end{array}$ & $\begin{array}{r}57.43 \\
72.42 \\
109.75 \\
\end{array}$ & $\begin{array}{l}611.40 \\
247.60 \\
885.49 \\
\end{array}$ & $\begin{array}{r}41.18 \\
140.33 \\
989.86 \\
\end{array}$ & $\begin{array}{l}269.75 \\
117.97 \\
999.86 \\
\end{array}$ \\
\hline $\begin{array}{l}\mathrm{Cr}-\text { Total } \\
\mathrm{Pb}-\text { Total } \\
\mathrm{Cu}-\text { Total } \\
\mathrm{Zn}-\text { Total } \\
\mathrm{Cd}-\text { Total } \\
\mathrm{Ni}-\text { Total }\end{array}$ & $\begin{array}{l}\mathrm{mg} \cdot \mathrm{kg}^{-1} \\
\text { dry mass }\end{array}$ & $\begin{array}{c}39.33 \\
40.40 \\
8.28 \\
70.25 \\
0.43 \\
30.08\end{array}$ & $\begin{array}{c}48.95 \\
59.25 \\
272.25 \\
1182.50 \\
5.10 \\
23.03\end{array}$ & $\begin{array}{c}33.85 \\
18.65 \\
74.50 \\
93.75 \\
0.28 \\
39.98\end{array}$ & $\begin{array}{l}11.55 \\
2.75 \\
1.18 \\
9.28 \\
0.05 \\
7.30\end{array}$ \\
\hline
\end{tabular}

corresponded to medium soil, and in terms of grain composition of sandy loam. It contained $62 \%$ of sand, $35 \%$ of silt and $3 \%$ of clay (Systematyka gleb Polski/ Classification of Polish Soils 2011).

The experiment was conducted in quadruplicate in polyethylene pots with a capacity of $6 \mathrm{~kg}$, filled with ash-sludge and ash-peat mixtures in the amount of $1-30 \%$ relative to the total weight of soil. The experimental design comprised also objects containing only single components of the mixtures (Table 2). Usual NPK fertilization in an amount of $0.3 \mathrm{~g}$ of N, $0.08 \mathrm{~g} \mathrm{P}, 0.2 \mathrm{~g} \mathrm{~K} \cdot \mathrm{kg}^{-1}$ of soil, in the form of $\mathrm{NH}_{4} \mathrm{NO}_{3}$, $\mathrm{KH}_{2} \mathrm{PO}_{4}, \mathrm{KCl}$ was used annually for all pots. Mineral fertilizers were applied in the form of solutions in the first two weeks before the sowing of the plants and thoroughly mixed with the substratum. In the second and third year of the experiment fertilizers were applied in early spring before the start of plant mixture vegetation. The mixture included: Festuca rubra L. $-47 \%$, Festuca arundinacea Schreb. - 17.5\%, Poa pratensis L. $-23.5 \%$, Lotus corniculatus L. $-12 \%$. During the growing season the plants were watered with redistilled water, and the soil moisture was maintained at $60 \%$ of maximum water capacity. The yield and content of heavy metals in the mixture of plants were stated in another paper (Antonkiewicz 2007).

The following properties were determined in the soil after the experiment: $\mathrm{pH}$ in $\mathrm{H}_{2} \mathrm{O}$ and $1 \mathrm{~mol} \cdot \mathrm{dm}^{-3}$ $\mathrm{KCl}$, hydrolytic acidity by Kappen's method, the base exchange capacity (BEC) in $1 \mathrm{~mol} \cdot \mathrm{dm}^{-3} \mathrm{CH}_{3} \mathrm{COONH}_{4}$, organic carbon content by Tiurin's method, nitrogen by Kieldahl's method, the content of available phosphorus and potassium by Egner-Riehm's method, and magnesium by Schatschabel's method (Antonkiewicz 2008). Total content of heavy metals was determined in the soil after dissolving the samples in a mixture of nitric and perchloric acids (3:2).

\section{Fractionation of heavy metals}

The determination of metal fractions in the tested substrates was made using sequential metals fractionation scheme proposed by Tessier et al. (1979). The extraction was aimed at differentiating fractions in five stages as follows:

1. metals soluble form, exchangeable metals (FI) air-dry and homogenized material was extracted with $8 \mathrm{~cm}^{3}$ of $1.0 \mathrm{~mol} \cdot \mathrm{dm}^{-3} \mathrm{MgCl}_{2}$ at $\mathrm{pH} 7$, by shaking for 1 hour at $25^{\circ} \mathrm{C}$.

2. metals bound to carbonates (FII) - the form of a exchangeable residue was extracted with $8 \mathrm{ml}$ of $1.0 \mathrm{~mol} \cdot \mathrm{dm}^{-3} \mathrm{CH}_{3} \mathrm{COONa}$, pH 5, by shaking constantly for 5 hours at $25^{\circ} \mathrm{C}$.

3. metals bound to iron and manganese oxides (FIII) - carbonate residue was extracted for five hours $20 \mathrm{~cm}^{3}$ of $0.04 \mathrm{~mol} \cdot \mathrm{dm}^{-3} \mathrm{NH}_{2} \mathrm{OH} \cdot \mathrm{HCl}$ dissolved in $25 \% \mathrm{CH}_{3} \mathrm{COOH}(\mathrm{vol} / \mathrm{vol})$ at $96^{\circ} \mathrm{C}$ stirring from time to time.

4. metals bound to organic matter (FIV) - residue form of Fe-Mn oxides was extracted $3 \mathrm{~cm}^{3} 0.02$ $\mathrm{mol} \cdot \mathrm{dm}^{-3} \mathrm{HNO}_{3}+5 \mathrm{~cm}^{3}$ of $30 \% \mathrm{H}_{2} \mathrm{O}_{2}(\mathrm{v} / \mathrm{v})$ for 2 hours at $85^{\circ} \mathrm{C}$, stirring occasionally, then $3 \mathrm{~cm}^{3}$ of $30 \% \mathrm{H}_{2} \mathrm{O}_{2}$ was added at $85^{\circ} \mathrm{C}$ while stirring from time to time. Finally the solution was shaken with $5 \mathrm{~cm}^{3}$ of $3.2 \mathrm{~mol} \cdot \mathrm{dm}^{-3} \mathrm{CH}_{3} \mathrm{COONH}_{4}$ in $20 \% \mathrm{HNO}_{3}$ (vol/vol) for 0.5 hour at $25^{\circ} \mathrm{C}$.

5. metal residue bound to silicates, residual fraction (FV) - the remains of organic form was hot decomposed with $10 \mathrm{~cm}^{3}$ of $40 \% \mathrm{HF}$ and $2 \mathrm{~cm}^{3}$ of $70 \%$ $\mathrm{HClO}_{4}, 1 \mathrm{~cm}^{3} \mathrm{HClO}_{4}$ was added after drying, and heated until white fumes appeared. The residue was dissolved in $\mathrm{HCl}(1: 1)$ and diluted to $100 \mathrm{~cm}^{3}$.

After each successive extraction, the samples were centrifuged at $4500 \mathrm{rpm}$ for $15 \mathrm{~min}$ (Legret et al. 1988). The supernatants were removed with pipette and filtered with Whatman filter paper no. 42. The residue was washed with deionized water followed by vigorous hand shaking and then followed $15 \mathrm{~min}$ of centrifugation before next extraction. The volume of rinse water used was kept to a minimum to avoid excessive solubilization of solid materials. In the filtrates from each replicate (pot), the content of $\mathrm{Cr}$, $\mathrm{Zn}, \mathrm{Pb}, \mathrm{Cu}, \mathrm{Cd}$, Ni present in the individual fractions was determined by ICP-AES method. 


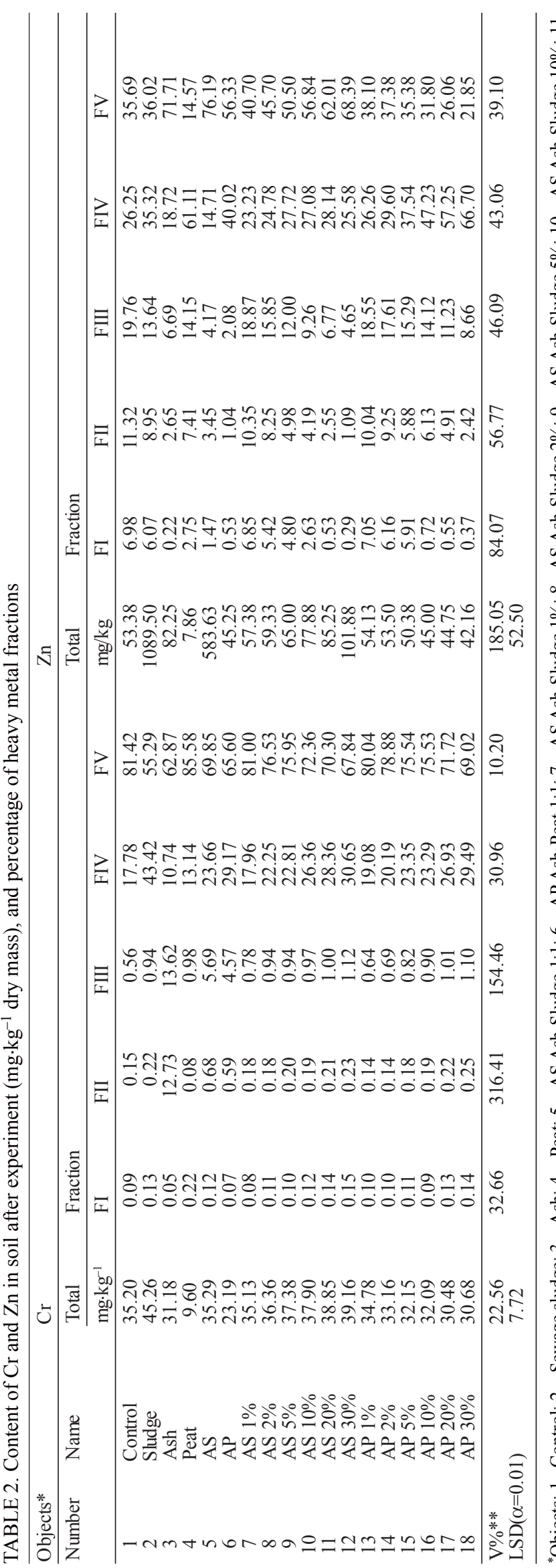

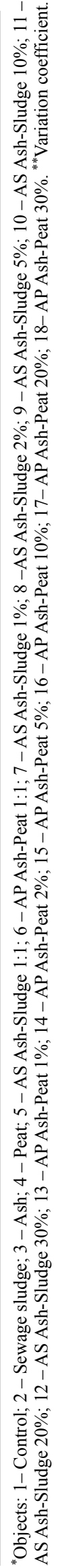

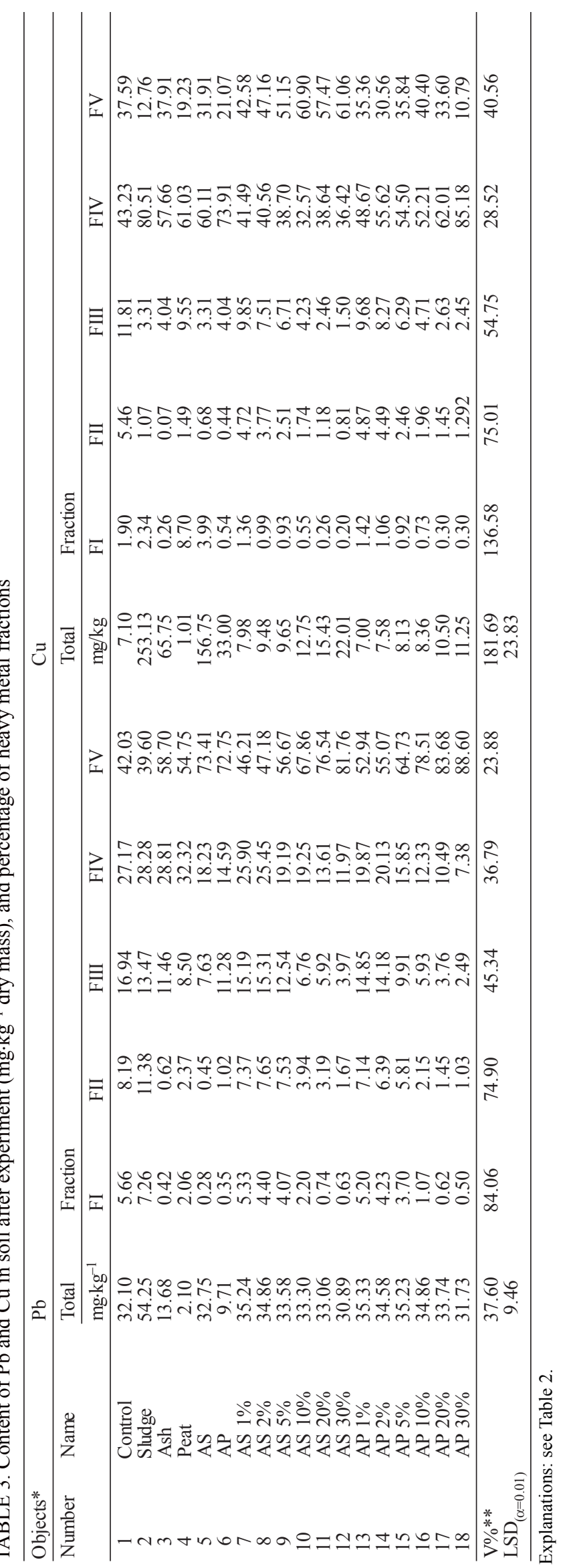




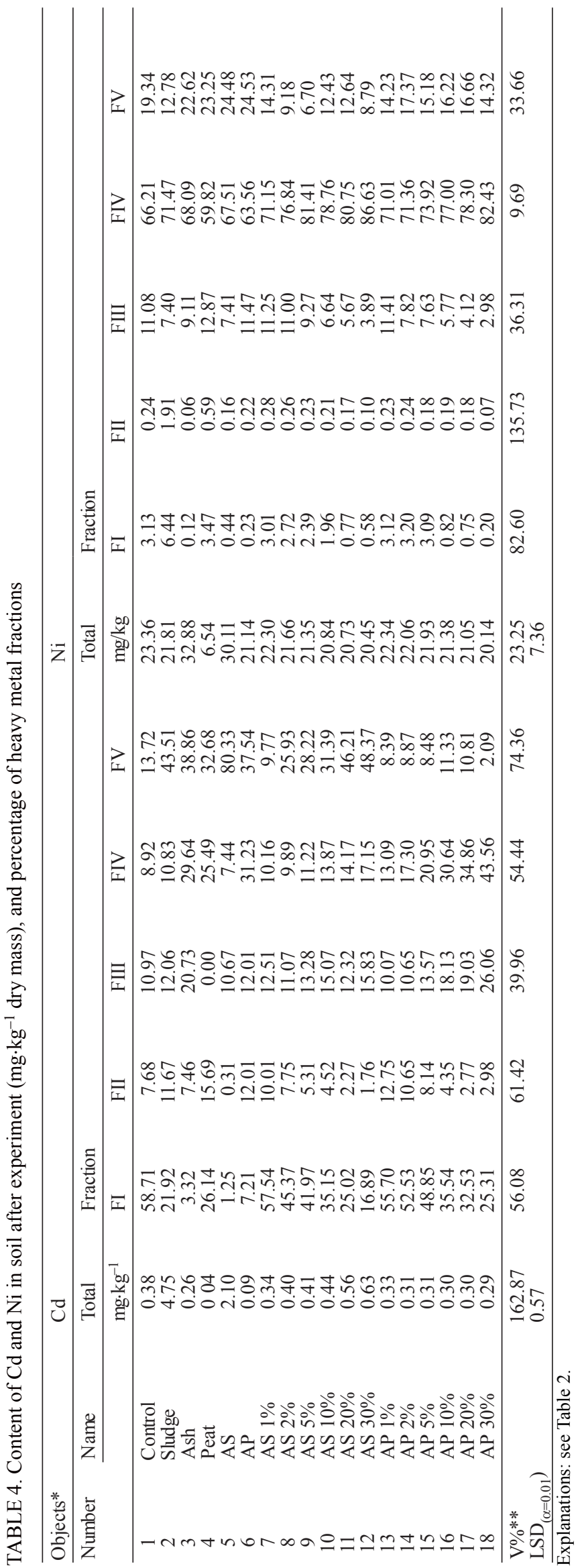

For statistical calculations Microsoft Excel spreadsheet 7.0 and Statistica v. 7.0 were used. Statistical evaluation of the different sources of variation was made using analysis of variance. The significance of differences between the compared averages of survey characteristics (performance indicators) was estimated on the basis of Tukey's T-test at the significance level for the pot experiments $\alpha=0.01$.

\section{RESULTS AND DISCUSSION}

The basic physicochemical properties of soil after application of municipal sewage sludge, peat, mixtures of ash-sludge and ash-peat was published in an earlier paper (Antonkiewicz 2008). The research shows that the use of municipal sewage sludge, peat, ash and mixtures of ash and sediment and peat ash mixtures in the experiment was the cause of increasing sorption capacity, content of available phosphorus, potassium and magnesium. The addition and ash, and mixtures of ash and sewage sludge and peat ash to the soil resulted in an increase of $\mathrm{pH}$. The result of peat and ash-peat mixtures application was the increase in organic carbon content in the soil.

\section{The content of heavy metals in soil and wastes}

The soil used in the experiment was characterized by the natural content of $\mathrm{Pb}, \mathrm{Cu}$ and $\mathrm{Cd}$, and the raised $\mathrm{Cr}$, Ni and $\mathrm{Zn}$ (Table 1), (Kabata-Pendias et al. 1995). Reported heavy metal content was below the acceptable amounts of these elements in soils classified for fertilization with municipal sewage sludge (Regulation 2010). Assessment of the content of heavy metals in the furnace ash according to the boundary numbers proposed by the Institute of Soil Science and Plant Cultivation (IUNG), Puławy, Poland (KabataPendias et al. 1995) revealed a natural content of these elements with the exception of copper. The content of heavy metals in the ash, as compared to the soil, was not high, and did not pose environmental hazard from incineration ash. Applied municipal sludge contained higher amounts of heavy metals as compared to incineration ash, however, the determined content of these metals did not exceed the limit values conditioning their environmental management (Regulation 2010).

In the municipal sludge (object 2) applied without additions, the contents of $\mathrm{Cr}, \mathrm{Zn}$ and $\mathrm{Cd}$ were, respectively, more than: $1.24,17,12$-fold higher than that in the soil. In comparison with the soil, sludge and ash, and their mixtures, peat (object 4) applied in the experiment without any supplements was charac- 
terized by the lowest content of the studied metals. The contents of $\mathrm{Cr}, \mathrm{Zn}, \mathrm{Pb}, \mathrm{Cu}, \mathrm{Cd}$, and $\mathrm{Ni}$ in peat was more than $72 \%, 85 \%, 93 \%, 85 \%, 89 \%, 72 \%$ lower compared to the soil.

After application of ash-sludge mixture (object 5) alone, a significant increase of $\mathrm{Zn}, \mathrm{Cd}$ and $\mathrm{Cu}$ was registered in the substrate, respectively more than $10.9,5.5,22$-fold higher than in control. In contrast, in the ash-peat mixture (object 6) a significantly lower content of $\mathrm{Cr}, \mathrm{Zn}, \mathrm{Pb}$, and $\mathrm{Cd}$ in the soil was noted as compared to the control, except for $\mathrm{Cu}$, for which more than 4-fold higher content was assessed in comparison to the control.

After three years of the plant mixture growing it was observed that under the influence of increased proportions of ash-sludge mixtures (objects 7-12), a systematic increase in $\mathrm{Cr}, \mathrm{Zn}, \mathrm{Cd}$ in the soil occurred, whereas a reduction of $\mathrm{Pb}$ and $\mathrm{Ni}$ in soil was recorded (Table 2-4). The increase in the content of $\mathrm{Cr}, \mathrm{Zn}$ and $\mathrm{Cd}$ in soil fertilized with ash-sludge mixtures is explained by the high content of these elements in municipal sewage sludge. Under the influence of increased proportions of ash-peat mixtures in the soil (objects 13-18) a decrease of $\mathrm{Cr}, \mathrm{Zn}, \mathrm{Pb}$, $\mathrm{Cd}$ and $\mathrm{Ni}$ in soil was noted (Table 2-4). Lowering the content of $\mathrm{Cr}, \mathrm{Zn}, \mathrm{Pb}, \mathrm{Cd}$ and $\mathrm{Ni}$ in soil may be explained by a low content of these elements in peat and ash. Application of ash and sewage sludge and ash-peat mixtures to the soil (objects 7-18) resulted in a systematic, though insignificant increase in the content of $\mathrm{Cu}$ in the substrata. The source of $\mathrm{Cu}$ in these objects was municipal sewage sludge and incineration ash, in which the content of this trace element was respectively more than 35 -fold and 9-fold higher compared to the contents in the soil. In the presented studies lower levels of heavy metals were assessed in ash-peat mixture (objects 13-18), in comparison to the amount of heavy metals in ashsludge mixtures (objects 7-12).

\section{Heavy metal fractions in soil and wastes}

Percentage distribution of individual metals varied between the separated fractions depending on the element in question, and the object (type and dose of waste). Percentage distribution of heavy metals in the individual fractions are shown in Tables 2, 3, and 4.

It was assumed in the study that most mobile (i.e. readily available to the plants) are the first two fractions (FI and FII). From the literature (Gworek et al. 2006; Shrivastava and Banerje 2004) it is known that water-soluble metal, interchangeable and related with carbonates (FI-FII) are very active forms, i.e. easily penetrating into the soil solution and absorbed by plants. Fractions strongly associated with trace metals from the soil solid phase (waste), mainly iron and manganese oxides and organic matter (FIII-FIV) are also a potential source of heavy metals to plants, but their release from the soil (waste) generally occurs more slowly. Metals forming aluminosilicate bonds (residue FV) are dissolved only in concentrated mineral acids and are believed to be unavailable to plants (Shrivastava and Banerje 2004; Legret 1993).

In the control soil, after 3 years of plant mixture cultivation the greatest share of $\mathrm{Cr}, \mathrm{Zn}, \mathrm{Pb}$ in the residual fraction (FV) was apparent, whereas the greatest share of $\mathrm{Cu}$ and $\mathrm{Ni}$ were found in the fraction bound to organic matter (FIV), and Cd in the exchangeable fraction (FI), (Table 2-4). The smallest share of $\mathrm{Cr}$ in the control soil was found in the most mobile fractions, i.e. in the form available to plants (fractions FI-FII), which did not exceed $0.24 \%$ of total Cr.

After a 3-year cultivation of plant mixture on municipal sludge (object 2) a low concentration of $\mathrm{Cr}$ was found in the mobile fractions and the sum of the first two fractions did not exceed $0.35 \%$ of the total content. The highest amounts of $\mathrm{Cr}, \mathrm{Zn}$ and $\mathrm{Pb}$ in the residual fraction (FV) and organic (FIV) were assessed in the sewage sludge applied without any supplements. $\mathrm{Cu}$ and $\mathrm{Ni}$ were most strongly bound by organic matter in the sludge, whereas the biggest content of Cd (over 43\%) was determined in the residual fraction and the exchangeable fraction (over $21 \%)$. A similar distribution of heavy metals in the fractions in wastes and sewage sludge were reported by other authors (Ațýk and Katkat 2010; Zhang et al. 2001).

In the ash used without any additions (object 3) metals such as $\mathrm{Cr}, \mathrm{Zn}, \mathrm{Pb}$ and $\mathrm{Cd}$ were mainly present in the residual fraction, and $\mathrm{Cu}$ and $\mathrm{Ni}$ in organic fraction (FIV). The best availability of heavy metals from the incineration ash (occurring in fractions FI-FII total), which exceeded respectively 12 and $10 \%$ of the total content was found for $\mathrm{Cd}$ and $\mathrm{Cr}$. Other tested metals such as $\mathrm{Zn}, \mathrm{Pb}, \mathrm{Cu}$ and $\mathrm{Ni}$ occurred in small quantities in the most mobile fractions (Table 2-4). A similar distribution of heavy metals in the fractions in ash was reported by other author (Chang et al. 2009). The contents of $\mathrm{Zn}, \mathrm{Pb}, \mathrm{Cu}$ and $\mathrm{Ni}$ in fractions FI-FII constituted respectively over: $2.88 \%, 1.04 \%, 0.34 \%$, $0.18 \%$ of the total content. The Author's own research (Antonkiewicz 2011) and literature data show that incineration ash accumulated the least of $\mathrm{Ni}$ and $\mathrm{Cu}$ in mobile fractions (Kalembkiewicz and Sočo 2004). Organic fraction (FIV), which was present in the ash as unburnt carbon residue, had the significant role in $\mathrm{Pb}, \mathrm{Cu}, \mathrm{Cd}$ and $\mathrm{Ni}$ binding and constituted respectively over: $28 \%, 57 \%, 29 \%, 68 \%$ of the total content. 
In the peat applied without any supplements (object 4$), \mathrm{Cr}, \mathrm{Pb}$ and $\mathrm{Cd}$ occurred mainly in the residual fraction (FV), and $\mathrm{Zn}, \mathrm{Cu}$ and $\mathrm{Ni}$ were mainly in the organic fraction (FIV). The peat showed the greatest share of $\mathrm{Cd}$ in the most mobile fractions (FI-FII). Cd content in these fractions exceeded more than $41 \%$ of the total content. Peat as a natural material is a rich source of organic matter, and binds heavy metals (Syrovetnik et al. 2008; Qin et al. 2006).

Ash-sludge mixture (object 5) and ash-peat mixture (object 6) accumulated the greatest amount of $\mathrm{Cr}, \mathrm{Zn}, \mathrm{Pb}$ and $\mathrm{Cd}$ in the residual fraction $(\mathrm{FV})$, whereas $\mathrm{Cu}$ and $\mathrm{Ni}$ was present in the organic fraction (FIV). Furthermore, ash-peat mixture (object 6) was the source of $\mathrm{Cd}$ for the plant mixture, because the sum of the most mobile fractions (FI-FII) made up more than $19 \%$ of the total content. Rosik-Dulewska et al. (2008) and Papadimitriou et al. (2008) confirmed that the ash-sediment mixtures accumulate heavy metals mainly in residual and organic fractions.

Ash-sewage sludge mixtures applied to the soil (objects 7-12) and ash-peat mixture (objects 13-18) contained $\mathrm{Cr}, \mathrm{Zn}, \mathrm{Pb}$, mainly in the residual fraction (FV), $\mathrm{Cu}$ and $\mathrm{Ni}$ in the organic fraction (FIV), whereas $\mathrm{Cd}$ in exchangeable fraction (FI). In ash-sludge mixtures (objects 7-12) and ash-peat mixtures (objects 13-18) a significant share of $\mathrm{Cr}, \mathrm{Zn}, \mathrm{Pb}$ was also found in the organic fraction (FIV). Hanani et al. (2010), and Hose and Brink (2004) confirmed that the fly ash and sewage sludge mixtures accumulate heavy metals mainly in organic and residual fractions.

The sum of the first two fractions (FI+FII), comprising the most mobile forms of metals, in the tested ash-sludge and ash-peat mixtures applied to the soil (objects 7-18), was diverse and depended on the object ranged as follows: $0.24-0.39 \% \mathrm{Cr}, 1.38-$ $17.19 \% \mathrm{Zn}, 1.53-12.70 \% \mathrm{~Pb}, 1.01-6.29 \mathrm{Cu}, 18.65-$ $68.46 \% \mathrm{Cd}, 0.27-3.44 \% \mathrm{Ni}$ of the total content (Table 2-4). Presented research shows that the greatest availability for plants characterized $\mathrm{Cd}$, then $\mathrm{Zn}, \mathrm{Pb}$, $\mathrm{Cu}, \mathrm{Ni}$, whereas $\mathrm{Cr}$ was the least available. In the pot experiment, it was found that the main role in the storage $\mathrm{Cr}, \mathrm{Zn}, \mathrm{Pb}$ had residual fraction $(\mathrm{FV})$, and $\mathrm{Cu}$ and $\mathrm{Ni}$ fraction associated with organic matter (FIV), and the fraction of exchangeable $\mathrm{Cd}(\mathrm{FI})$ and a residual fraction (FV).

In result of sewage sludge mixing with furnace ash a decline in heavy metal quantities in the fractions most available to plants was registered. The greater the share of ash in the mixture, the smaller proportion of the metals in forms bioavailable to plants was found. A mixture of ash and sewage sludge and ash and peat restrict the mobility of heavy metals in environmental (Weidong et al. 2010; Xua et al. 2012). As a result of ash-sludge mixtures application an increase in $\mathrm{Cr}$ contents in fractions most available to plants (FI-FII) was detected in soil, whereas percentage of $\mathrm{Zn}, \mathrm{Pb}$, $\mathrm{Cu}, \mathrm{Cd}$ and $\mathrm{Ni}$ in these fractions decreased systematically.

\section{CONCLUSIONS}

1. The use of the sewage sludge increases the total content of $\mathrm{Cr}, \mathrm{Zn}, \mathrm{Pb}, \mathrm{Cu}, \mathrm{Cd}$ and reduces the content of $\mathrm{Ni}$ in the soil as compared to the control. However, the addition of ash reduces the contents of $\mathrm{Cr}, \mathrm{Pb}, \mathrm{Cd}$ and increases the total content of $\mathrm{Zn}$, $\mathrm{Cu}$ and $\mathrm{Ni}$ in the soil. The use of peat reduces the total content of tested metals in the soil. In the conditions of the use of increasing amounts of the mixture of sludge with ash a systematic increase in the total content of $\mathrm{Cr}, \mathrm{Zn}, \mathrm{Cu}$ and $\mathrm{Cd}$ and $\mathrm{Pb}$ decrease and Ni content in the soil is observed. The addition of increasing amounts of mixture of ash with peat to the soil contributes to the gradual reduction of the total content of $\mathrm{Cr}, \mathrm{Zn}, \mathrm{Pb}, \mathrm{Cd}$ and $\mathrm{Ni}$ in the soil which may be explained by a low content of these elements in the peat.

2. Municipal sewage sludge was the largest source of heavy metals present in the fractions most available to plants (FI-FII), however the incineration ash contained the smallest amount of heavy metals present in these fractions.

3. A decrease in the amount of heavy metals present in the fractions the best available to plants was observed after mixing ash with sewage sludge. The greater the part of ash in the ash-sludge mixtures, the smaller the share of metals in forms available to plants.

4. Ash-sludge and ash-peat mixtures applied to the soil contained $\mathrm{Cr}, \mathrm{Zn}, \mathrm{Pb}$, mainly in the residual fraction (FV), $\mathrm{Cu}$ and $\mathrm{Ni}$ in the organic fraction (FIV), and Cd in the exchangeable fraction (FI).

5. It was found that the materials used in the experiment limited the mobility of heavy metals, as evidenced by the small share of exchangeable forms. Thus, these materials reduce the availability of these elements to plants.

\section{REFERENCES}

Al-Ani H., Oh E, Chai G., 2014. GIS-based examination of peats and soils in Surfers Paradise, Australia. Soil Science Annual, 65(1): 29-38.

Antonkiewicz J., 2007. Wpływ różnych mieszanin popiołowoosadowych i popiołowo-torfowych na plon i zawartość pierwiastków w mieszance traw z komonicą zwyczajną. Cześć II Metale ciężkie. (The influence of various ash-and-sludge and ash-and-peat mixtures on yield and elements content in grass- 
birdsfoot-trefoil mixture. Part II. Heavy metals). Zeszyty Problemowe Postępów Nauk Rolniczych - Advances of Agricultural Sciences Problem Issues, 520: 265-278.

Antonkiewicz J., 2008. Wpływ komunalnego osadu ściekowego, popiołu paleniskowego, torfu i ich mieszanin na właściwości fizykochemiczne oraz zawartość metali ciężkich w glebie. (Influence of municipal sewage sludge incineration ash, peat and their mixtures on physicochemical properties and the heavy metals content in soil). Roczniki Gleboznawcze - Soil Science Annual, 59(1): 18-28.

Antonkiewicz J., 2011. Ocena biodostępności metali ciężkich w odpadach zastosowanych do przyrodniczej rekultywacji składowiska odpadów niebezpiecznych. (Assessment of bioavailability of heavy metals in wastes used for biological reclamation of hazardous waste landfill). Zeszyty Naukowe Uniwersytetu Rolniczego w Krakowie, Nr 484, Seria Rozprawy 358, ss. 119 - Scientific Papers of the University of Agriculture in Krakow, No 481, Series Dissertation 358, 119 pp.

Ațýk B.B., Katkat A.V., 2010. Evaluation of wastewater sludge for possible agricultural use. Environmental Engineering and Management Journal, 10(6): 819-826.

Chang C-Y, Wang C-F, Mui D.T., Chiang H-L., 2009. Application of methods (sequential extraction procedures and highpressure digestion method) to fly ash particles to determine the element constituents: A case study for BCR 176. Journal of Hazardous Materials, 163: 578-587.

Dąbrowska L., Rosińska A., Janosz-Rajczyk M., 2011. Heavy metals and PCBs in sewage sludge during thermophilic digestion process. Archives of Environmental Protection, 37(3): $3-13$.

Gworek B., Mocek A., Kondzielski I., 2006. Speciation of copper in industrially polluted soils - a comparison of two sequential extraction methods. Polish Journal of Environmental Studies, 15(2a): 295-303.

Hanani M.N., Fauziah I.C., Samsuri A.W., Zauyah S., 2010. Formulation of Coal Fly Ash and Sewage Sludge Mixtures to Reduce Impacts on the Environment When Used as Soil Ameliorant for Acidic Tropical Soils. Malaysian Journal of Soil Science, 14: 53-70.

Hose G.C., Van den Brink P.J., 2004. Confirming the SpeciesSensitivity Distribution Concept for Endosulfan Using Laboratory, Mesocosm, and Field Data. Archives of Environmental Contamination and Toxicology, 47: 511-520.

DOI: $10.1007 / \mathrm{s} 00244-003-3212-5$.

Kabata-Pendias A., Piotrowska M., Motowicka-Terelak T., Maliszewska-Kordybach T., Filipiak K., Krakowiak A., Pietruch C., 1995. Podstawy oceny chemicznego zanieczyszczenia gleb - metale ciężkie, siarka i WWA. (Basis for the assessment of chemical contamination of soil - heavy metals, sulfur and PAHs). Państwowa Inspekcja Ochrony Środowiska. Biblioteka Monitoringu Środowiska - State Inspectorate for Environmental Protection. Library of Environmental Monitoring, Warsaw, pp. 41.

Kalembkiewicz J., Sočo E., 2004. Sequential extraction of Cr, $\mathrm{Fe}, \mathrm{Co}$, and $\mathrm{Ni}$ from industrial ash. Ecological Chemistry and Engineering, 11 (4-5): 347-352.

Legret M., 1993. Speciation of heavy metals in sewage sludge and sludge-amended soil. International Journal of Environmental Analytical Chemistry, 51: 161-166.

Legret M., Diver L and Juste C., 1988. Movement and speciation of heavy metals in a soil amended with sewage sludge conta- ining large amount of cadmium and nickel. Water Research, 22(8): 953-969.

Papadimitriou C.A., Haritou I., Samaras P., Zouboulis A.I., 2008. Evaluation of leaching and ecotoxicological properties of sewage sludge-fly ash mixtures. Environmental Research, 106: 340-348.

Qin F., Wen B., Shan X-Q, Xie Y-N, Liu T., Zhang S-Z., Khan S.U., 2006. Mechanisms of competitive adsorption of $\mathrm{Pb}, \mathrm{Cu}$, and $\mathrm{Cd}$ on peat. Environmental Pollution, 144: 669-680.

Regulation, 2010. Regulation of the Minister of the Natural Environment on municipal sewage sludge dated 13 July 2010. Journal of Laws of Poland, No 137, Item 924.

Rosik-Dulewska C., Głowala K., Karwaczyńska U., Robak J., 2008. Elution of heavy metals from granulates produced from municipal sewage deposits and fly-ash of hard and brown coal in the aspect of recycling for fertilization purposes, Archives of Environmental Protection, 34(2): 63-72.

Samaras P., Papadimitriou C.A., Haritou I., Zouboulis A.I., 2008. Investigation of sewage sludge stabilization potential by the addition of fly ash and lime. Journal of Hazardous Materials, 154: 1052-1059.

Shrivastava S.K., Banerje D.K., 2004. Speciation of metals in sewage sludge and sludge-amended soils. Water, Air, and Soil Pollution, 152: 219-232.

Sienkiewicz S., Czarnecka M.H., 2012. Content of available Cu, $\mathrm{Zn}$ and $\mathrm{Mn}$ in soil amended with municipal sewage sludge. Journal of Elementology, 17(4): 649-657.

DOI: $10.5601 /$ jelem. 2012.17.4.08.

Sočo E., Kalembkiewicz J., 2007. Investigations of sequential leaching behaviour of $\mathrm{Cu}$ and $\mathrm{Zn}$ from coal fly ash and their mobility in environmental conditions. Journal of Hazardous Materials, 145: 482-487.

Syrovetnik K., Malmström M.E., Neretnieks I., 2008. Modelling retention of heavy metals in the Oostriku peat bog, Estonia: Comparison of predicted and observed results. Applied Geochemistry, 23: 1498-1512.

Systematyka gleb Polski (Classification of Polish Soils), 2011. Roczniki Gleboznawcze - Soil Science Annual, 62(3): 1-193.

Tessier A., Campbell P.G.C., Bisson M., 1979. Sequential extraction procedure for the speciation of particulate trace metals. Analytical Chemistry, 51(7): 844-851.

Weidong L., Ming L., Weifeng L., Haifeng L., 2010. Study on the ash fusion temperatures of coal and sewage sludge mixtures. Fuel, 89: 1566-1572.

Xua J-Q., Yua R-L., Dongb X-Y., Hua G-R., Shanga X-S., Wangc Q., Li H-W., 2012. Effects of municipal sewage sludge stabilized by fly ash on the growth of Manilagrass and transfer of heavy metals. Journal of Hazardous Materials, 217-218: 58-66.

Zhang F.-S., Yamasaki S.-I, Nanzyo M., Kimura K., 2001. Evaluation of cadmium and other metal losses from various municipal wastes during incineration disposal. Environmental Pollutions, 115: 253-260.

Zhang Z., Qi H., Ren N., Li Y., Gao D., Kannan K., 2011. Survey of Cyclic and Linear Siloxanes in Sediment from the Songhua River and in Sewage Sludge from Wastewater Treatment Plants, Northeastern China. Archives of Environmental Contamination and Toxicology, 60: 204-211. DOI 10.1007/s00244-010-9619-x.

Received: November 5, 2014

Accepted: November 25, 2014 


\section{Frakcje metali ciężkich w glebie po zastosowaniu komunalnego osadu ściekowego, popiołu paleniskowego i torfu}

Streszczenie: Badano wpływ dodatku różnych materiałów, tj.: osadu ściekowego, popiołu i torfu oraz różnych dawek mieszanin popiołowo-osadowych i popiołowo-torfowych, na całkowitą zawartość metali ciężkich ( $\mathrm{Cr}, \mathrm{Zn}, \mathrm{Pb}, \mathrm{Cu}, \mathrm{Cd}, \mathrm{Ni})$ oraz ich frakcje. Zastosowanie w doświadczeniu osadu ściekowego oraz mieszanin popiołowo-osadowych i popiołowo-torfowych powodowało stopniowy wzrost zawartości badanych metali ciężkich w glebie. Popiół charakteryzował się niską zawartościa metali ciężkich w porównaniu do komunalnych osadów ściekowych. W wyniku zastosowania torfu oraz jego mieszanin popiołowo-torfowych nastapiło obniżenie zawartości badanych metali ciężkich, sam zaś torf był źródłem największego wzrostu zawartości węgla organicznego. Rozmieszczenie metali ciężkich we frakcjach wyodrębnionych w różnych kombinacjach, charakteryzowało duże zróżnicowanie w zależności od badanego metalu i zastosowanego podłoża. Główną rolę w magazynowaniu chromu, cynku, ołowiu i kadmu pełniła frakcja pozostałości (FV), zaś najwięcej miedzi i niklu związane było z materią organiczną (FIV). Stwierdzono, że wprowadzanie do gleby materiałów o charakterze alkalicznym jest przyczyną małej rozpuszczalności większości metali ciężkich, przez co ograniczone jest ich pobieranie przez rośliny. Wyjątek stanowiły chrom i miedź, których rozpuszczalność wzrastała wraz ze wzrostem zasadowości.

Słowa kluczowe: osad ściekowy, torf, popioły paleniskowe, gleba, frakcje metali ciężkich 